\title{
UPAYA MENINGKATKAN HASIL BELAJAR PESERTA DIDIK KELAS V SDN 3 ANJIR MAMBULAU TIMUR KECAMATAN KAPUAS PADA MATA PELAJARAN IPA DENGAN MENGGUNAKAN METODE PEMBELAJARAN DOUBEL LOOP PROBLEM SOLVING (DLPS) DAN MEDIA AUDIO VISUAL TAHUN PELAJARAN 2016/2017
}

\author{
Oleh \\ Raymullah Rahman', Chandra Anugrah Putra ${ }^{2}$
}

\begin{abstract}
ABSTRAK
Penelitian ini bertujuan : (1) Untuk mendeskripsikan aktivitas belajar peserta didik kelas V SDN-3 Anjir Mambulau Timur pada mata pelajaran IPA dengan menggunakan Metode Double Loop Problem Solving (DLPS) Dan Media Audio Visual.dan, (2) Untuk mengetahui peningkatan hasil belajar IPA dengan menggunakan Metode Double Loop Problem Solving (DLPS) Dan Media Audio Visual. pada peserta didik kelas V SDN-3 Anjir Mambulau Timur tahun pelajaran 2016/2017.

Metode penelitian yang digunakan dalam penelitian ini adalah metode Penelitian Tindakan Kelas (PTK). Subyek penetian yaitu peserta didik kelas V SDN-3 Anjir Mambulau Timur dengan jumlah 13 orang peserta didik yang terdiri dari 5 orang laki-laki dan 8 orang perempuan.Teknik analisis data menggunakan kualitatif dan kuantitatif.

Dari hasil penelitian disimpulkan bahwa : (1) Aktivitas belajar peserta didik kelas V SDN-3 Anjir Mambulau Timur dengan menggunakan Metode Double Loop Problem Solving (DLPS) Dan Media Audio Visual.pada mata pelajaran IPA menjadi lebih baik. Ini dibuktikan dari hasil rata-rata pada data hasil observasi aktivitas peserta didik pada siklus I yaitu 2,87 meningkat menjadi 3,3 pada siklus II,(2) Ada peningkatan hasil belajar IPA dengan menggunakan Metode Double Loop Problem Solving (DLPS) Dan Media Audio Visual. Ini terlihat dari perolehan nilai rata-rata setiap siklus semakin meningkat. Pada siklus I memperoleh nilai rata-rata 71 dan ketuntasan klasikal $84 \%$ termasuk dalam kriteria tidak tercapai dan pada siklus II meningkat menjadi 77 dan ketuntasan klasikal 100\% termasuk kriteria tercapai.
\end{abstract}

(C) Universitas Muhammadiyah Palangkaraya

Kata Kunci: Hasil belajar, IPA, Double Loop Problem Solving (DLPS), Media Audio Visual

\section{PENDAHULUAN}

Pendidikan pada hakikatnya

merupakan usaha membudayakan manusia atau memanusiakan manusia untuk usaha sadar dan terencana untuk mewujudkan suasana belajar dan proses pembelajaran agar peserta didik secara aktif mengembangkan potensi dirinya untuk memiliki kekuatan spiritual 
keagamaan, pengendalian diri, kepribadian, kecerdasan, akhlak mulia,serta keterampilan yang diperlukan dirinya, masyarakat bangsa dan negara.

Peningkatan mutu pendidikan ditentukan oleh kesiapan sumber daya manusia yang terlibat dalam proses pendidik. Pendidik memiliki peran yang sangat penting dalam menentukan kuantitas dan kualitas peserta didik. Untuk memenuhi hal tersebut diatas, guru dituntut mampu mengelola proses belajar

mengajar yang baik untuk merangsang peserta didik lebih giat terutama dalam proses belajar.

Pendidikan sangat penting bagi anusia,karena dengan pendidikan manusia memperoleh kemampuan dan kecerdasan sehingga dapat mengembangkan potensi,sikap dan tingkah laku.Hal ini terdapat dalam Undang-Undang RI No.20 Tahun 2003 SISDIKNAS pasal 1:1 (2003:3) bahwa:

Pendidikan adalah usaha sadar dan terencana untuk mewujudkan suasana belajar dan proses pembelajaran agar peserta didik secara aktif mengembangkan potensinya untuk memiliki kekuatan spiritual keagamaan, pengendalian diri ,kepribadian ,kecerdasan ,akhlak mulia serta keterampilan yang diperlukan dirinya, masyarakat, bangsa dan negara.

Sistem pendidikan yang modern berfungsi pendidik sebagai penyampaian pesan-pesan pendidikan yang perlu dibantu dengan menggunakan metode misalnya Double Loop Problem Solving untuk melatih peserta didik untuk berfikir dengan kreatif. Hal ini disebabkan karena tugas guru merupakan pekerjaan yang profesional yang membutuhkan kemampuan dan kewenangan. Kemampuan guru dalam menjalankan perannya sebagai pengajar, administrator dan Pembina ilmu dapat dilihat dari sejauh manakah guru dapat menguasai metodologi media pendidikan di sekolah untuk kepentingan anak didiknya.

Menurut Ahmad Susanto (2013:5) bahwa hasil belajar yaitu perubahan-perubahan yang terjadi pada diri siswa, baik yang menyangkut aspek kognitif, afektif, dan psikomotor sebagai hasil dari kegiatan belajar.

Menurut Sri Anitah W, dkk (2011:2.19) bahwa: Hasil belajar merupakan kulminasi dari suatu proses yang telah dilakukan dalam belajar. Kulminasi akan selalu diiringi dengan kegiatan tindak lanjut. Hasil belajar harus menunjukkan suatu perubahan tingkah laku atau perolehan perilaku yang baru dari siswa yang bersifat menetap, fungsional, positif, dan disadari.

Menurut Asih Widi Wisudawati dan Eka Sulisyowati (2015:23) Menyatakan bahwa IPA adalah pengetahuan yang Ilmiah,pengetahuan yang diperoleh secara ilmiah,artinya di peroleh dengan metode yang ilmiah Dua sifat utama ilmu adalah rasional.artinya masuk akal,logis dan dapat diterima akal sehat dan objektif.Artinya sesuai dengan objeknya sesuai dengan kenyataan atau sesuai dengan pengamatan.

Menurut H. Moch. Agus Krisno Budiyanto (2016:58) DLPS ( 
Double Loop Problem Solving) adalah variasi dari pembelajaran dengan pemecahan masalah dengan penekanan pada pencarian kausal (penyebab) utama dari timbulnya masalah,jadi berkenaan dengan jawaban untuk pertanyaan mengapa.selanjutnya menyelesaikan masalah tersebut dengan cara menghilangkan apa yang menyebabkan munculnya masalah tersebut.DLPS juga merupakan salah satu metode yang banyak di gunakan untuk menunjang pendekatan pembelajaran yang mengajak peseta didik untuk aktif dalam kegiatan belajar mengajar.

Menurut Sri Anitah W, dkk (2011:6.30) menyatakan bahwa kombinasi audio dan visual atau biasa di sebut media pandang dengar.sudah barang tentu apabila anda menggunakan media ini akan semakin lengkap dan

\section{METODE PENELITIAN}

Jenis penelitian yang digunakan dalam Penelitian ini adalah rancangan Penelitian Tindakan Kelas (PTK). Menurut Arikunto (Jasman Jalil, 2014;6) PTK adalah gabungan pengertian dari kata penelitian tindakan, dan kelas. Penelitian adalah kegiatan mengamati suatu objek, dengan menggunakan kaidah metodologi tertentu untuk mendapatkan data yang bermanfaat bagi penelitian dan orang lain demi kepentingan bersama.Suatu penelitian akan menghasilkan kesimpulan yang tepat, apabila menggunakan jenis penelitian yang tepat dan benar sesuai dengan masalah optimal penyajian bahan ajar kepada para siswa,selain dari itu media ini dalam batas-batas tertentu dapat menggantikan peran dan tugas guru.dalam hal ini,guru tidak selalu berperan sebagai penyaji materi (tacher),tetapi penyaji materi bias diganti oleh media audio visual maka peran guru bias berubah menjadi fasilitator belajar,yaitu memberikan kemudahan bagi para siswa untuk belajar.Contoh dari media audiovisual di antaranya program video/ televisi pendididikan,video/televisi

instruksional,program slide suara (sound slide) dan program CD interaktif.

Media audio visual merupakan media pembelajaran tampak dengar yang dapat digunakan untuk menyampaikan pesan-pesan/materi pelajaran.

yang diteliti, situasi, dan kondisi saat penelitian tersebut dilakukan.

Menurut Suaidin (Jasman Jalil, 2014;6) PTK didefinisikan sebagai suatu bentuk kajian reflektif oleh guru sebagai pelaku tindakan yang bertujuan untuk meningkatkan kemampuan rasional dalam melaksanakan tugas keguruannya, memperdalam pemahaman terhadap tindakan yang dilakukannya, serta memperbaiki pembelajaran yang dilakukan.

Alur siklus penelitian Tindakan Kelas tersebut, dijelaskan sebagai berikut:

1. Rencana Umum

a. Menetapkan peneliti mitra (observer) yaitu Kepala Sekolah 
SDN 3 Anjir Mambulau Timur. Membangun kesepahaman antara peneliti dengan observer tentang konsep dan pelaksanaan Penelitian Tindakan Kelas, topik yang diangkat dalam proses pembelajaran, serta penentuan waktu pelaksanaan kegiatan Penelitian Tindakan Kelas.

b. Dalam hal ini dijabarkan dalam bentuk perencanaan (rencana) guru sebelum melakukan suatu tindakan. Rencana ini meliputi;

i. Tujuan yang akan dicapai dalam proses kegiatan belajar IPA.

ii. Kegiatan yang akan dilakukan dalam proses kegiatan belajar IPA.

iii. Menentukan metode yang ingin dipakai dengan mempertimbangkan kondisi peserta didik.

iv. Menyiapkan media dan perlengkapan yang diperlukan dalam kegiatan belajar

v. Menyiapkan materi yang akan diajarkan

2. Pelaksanaan Tindakan

Merupakan pelaksanaan tindakan yang dilakukan untuk

\section{HASIL DAN PEMBAHASAN}

\section{Deskripsi Data Pra Tindakan (Data Awal)}

Data pra tindakan terdiri atas data hasil tes awal (pre test). Data awal ini bertujuan untuk mengetahui tingkat kemampuan awal peserta didik terhadap materi yang akan di jadikan topik pembelajaran memotivasi peserta didik dalam belajar IPA (Ilmu Pengetahuan Alam). Upaya-upaya yang dilakukan guru untuk meningkatkan motivasi peserta didik dengan Metode Double Loop Problem Solving meliputi;

a. Menjalin kebersamaan dan saling memahami.

b. Memberikan pengalaman kepada peserta didik tentang pembelajaran IPA.

c. Memberikan peluang untuk menterjemahkan dan menerapkan pengetahuan mereka kedalam pembelajaran yang lain ke dalam kehidupan mereka.

d. Memberikan umpan balik atas apa yang mereka lakukan setelah

e. mereka belajar.

3. Observasi

Pada tahap ini peneliti dan observer (penilai) mengobservasi tindakan yang dilakukan dengan menggunakan format yang telah dikembangkan pada perencanaan dan memberi hasil pelaksanaan.

4. Refleksi

Refleksi pada tahapan ini dan observer (penilai) melakukan evaluasi tindakan dan melakukan pertemuan untuk membahas hasil.

sebelum penelitian tindakan kelas berlangsung. Adapun bentuk tes yang di lakukan dengan memberikan soal pilihan ganda sebanyak 20 butir dari pembelajaran IPA pada materi Peristiwa Alam dan Dampaknya bagi kehidupan manusia. Adapun data awal dari 13 orang peserta didik terdapat 10 orang peserta 
didik yang mendapatkan skor hasil IPA masih rendah yakni kurang dari nilai KKM yaitu 60 yang telah di tentukan oleh sekolah. Skor nilai tes awal selanjutnya di jadikan sebagai nilai dasar untuk menghitung peningkatan hasil belajar peserta didik pada siklus I.

2. Data Hasil Belajar IPA pada Siklus I

Berdasarkan perhitungan nilai ratarata dan ketuntasan belajar didapat dari hasil siklus I peserta didik kelas V SDN 3 Anjir Mambulau Timur di dapat rata-rata sebesar 71 dengan ketuntasan belajar sebesar $84 \%$ yang termasuk dalam kategori kurang tercapai. Nilai rata-rata peserta didik yang sebesar 71 masih belum mencapai kriteria ketuntasan minimal (KKM) yaitu 60 dan nilai ketuntasan belajar sebesar $84 \%$ masih kurang dari kriteria ketuntasan secara klasikal yaitu $85 \%$. Sehingga pada Siklus I tingkat ketercapaian keberhasilan pembelajaran masih belum memenuhi syarat ketuntasan hasil belajar

3. Data Hasil Belajar IPA pada Siklus II

Berdasarkan hasil perhitungan ketuntasan hasil belajar, maka dapat dilihat ketuntasan hasil belajar peserta didik pada tes awal siklus II adalah $100 \%$. Berdasarkan perhitungan nilai rata-rata dan ketuntasan klasikal hasil belajar, di dapat hasil tes siklus II terlihat dari nilai hasil belajar IPA pada materi Peristiwa Alam dan Dampaknya bagi kehidupan manusia peserta didik kelas V SDN 3 Anjir
Mambulau Timur di dapat nilai rata-rata sebesar 77 dan ketuntasan hasil belajar sebesar $100 \%$. Hal ini menunjukkan bahwa kemampuan peserta didik tersebut dapat di kategorikan tuntas, Ketuntasan hasil belajar dari siklus I ke siklus II pun meningkat sebesar $16 \%$ yaitu dari $84 \%$ ke $100 \%$. Hal tersebut sudah memenuhi standar Ketuntasan Klasikal $\geq 85 \%$ dengan nilai rata-rata kelas belajar $\geq 60$. Dengan demikian, peneliti menghentikan tindakan kelas ini sampai pada siklus II saja.

4. Aktivitas Peserta Didik pada Proses Pembelajaran Siklus I dan Siklus II.

Aktivitas Peserta Didik pada Pembelajaran Siklus I dan Siklus II

\begin{tabular}{|l|l|l|}
\hline No & Siklus & $\begin{array}{l}\text { Siklus } \\
\text { Rata-rata }\end{array}$ \\
\hline 1. & Siklus I & 2,87 \\
\hline 2. & Siklus II & 3,33 \\
\hline
\end{tabular}
aktivitas belajar peserta didik mengalami peningkatan disetiap siklusnya, hal itu dapat dilihat dari hasil lembar observasi peserta didik pada siklus I skor rata-rata yang diperoleh peserta didik adalah 2,87 dan pada siklus II skor rata-rata menjadi 3,33.

5. Hasil belajar IPA peserta didik kelas V SDN 3 Anjir Mambulau Timur setelah Menggunakan Metode Double Loop Problem Solving (DLPS) Dan Media Audio Visual

Berdasarkan analisis data yang dilakukan terhadap peserta 
didik, maka dapat disimpulkan dan dapat diperoleh hasil belajar tes awal memperoleh nilai rata-rata 46 dengan ketuntasan klasikalnya 23\% dimana ada 3 peserta didik yang belum tuntas karena masih kesulitan dalam memahami materi Peristiwa Alam dan dampaknya bagi kehidupan manusia sehingga peneliti memutuskan untuk melanjutkan ke siklus I di mana pada siklus I peneliti menerapkan metode pembelajaran dan dengan berbantuan media agar memudahkan peserta didik lebih memahami matari yang sedang diajarkan oleh peneliti.

Data hasil hasil belajar peserta didik siklus I pada hari Rabu, 26 April 2017 diperleh bahwaa hasil belajar peserta didik Menggunakan Metode Double Loop Problem Solving (DLPS) Dan Media Audio Visual memperoleh nilai rata-rata 71 dengan ketuntasan klasikalnya $84 \%$. Pada siklus I ini terdapat 2 peserta didik yang masih belum tuntas karena masih

\section{SIMPULAN}

Berdasarkan hasil penelitian, maka dapat disimpulkan beberapa hal sebagai berikut :

1. Aktivitas belajar peserta didik kelas V SDN 3 Anjir Mambulau Timur dengan menggunakan Metode Double Loop Problem Solving (DLPS) Dan Media Audio Visual menjadi baik. Hal ini dibuktikan dari hasil rata-rata aktivitas pada data hasil observasi peserta didik kesulitan dalam memahami materi tentang Peristiwa Alam dan dampaknya bagi kehidupan manusia sehingga pembelajaran IPA secara keseluruhan belum mencapai ketuntasan klasikal yang ditetapkan yaitu $85 \%$. Oleh sebab itu, peneliti memutuskan untuk melanjutkan penelitian ke siklus II dengan merefleksikan beberapa kegiatan pembelajaran.

Data hasil belajar peserta didik pada siklus II memperoleh nilai rata-rata 77 dengan ketuntasan klasikalnya $100 \%$ sehingga hal tersebut telah mencapai indikator keberhasilan penelitian yang telah ditetapkan yaitu hasil belajar peserta didik mencapai KKM $\geq 60$ dengan ketuntasann klasikal $85 \%$. Berdasarkan hasil penelitian tersebut maka ada peningkatan hasil belajar IPA peserta didik kelas V SDN 3 Anjir Mambulau Timur dengan Menggunakan Metode Double Loop Problem Solving (DLPS) Dan Media Audio Visual.

pada siklus I peserta didik memperoleh skor rata-rata 2,87 dengan kriteria cukup baik. Kemudian pada siklus II meningkat dengan skor rata-rata 3,33 kriteria baik.

2. Ada peningkatan hasil belajar IPA dengan menggunkan Metode Double Loop Problem Solving (DLPS) Dan Media Audio Visual pada peserta didik kelas V SDN 3 Anjir Mambulau Timur. Ini terlihat 
dari nilai rata-rata hasil belajar peserta didik saat pra tindakan yaitu 46 dan ketuntasan klasikal 23\% dengan kategori tidak tercapai. Adapun nilai rata-rata pada siklus I

\section{DAFTAR PUSTAKA}

Susanto, Ahmad. (2013). Teori Belajar dan Pembelajaran. Jakarta: Prendamedia Group.

Anitah W, Sri. Dkk. (2011).Strategi Pembelajaran di SD. Jakarta: Universitas Terbuka.

Wisudawati Widi \& Eka Sulistyowati (2015) Metodologi pembelajaran IPA:Jakarta adalah 71 dan ketuntasan klasikal 84\% dengan kategori tidak tercapai. Pada siklus II adalah 77 dan ketuntasan klasikal $100 \%$ dengan kategori tercapai.
Budiyanto Krisno Agus. Moch (2016) Sintaks $45 \quad$ Metode Pembelajaran dalam Student Centered Learning

(SCL):Malang Umm Press Jalil, Jasman (2014), Panduan Mudah Penelitian Tindakan Kelas (PTK), Jakarta Prestasi Pusat Karya (Group Relasi Inti Media)

Bumi Aksara 